УДК 618.3-06: 616.8-009.24-036.3] -036.1: 618.2-036.8

DOI 10.11603/24116-4944.2018.2.9572

\author{
${ }^{\odot}$ Ben Amor Mariam, O. P. Gnatko, N. G. Skuriatina \\ O. Bohomolets National Medical University, Kyiv
}

\title{
OBSTETRIC AND PERINATAL OUTCOMES IN PREGNANCY WITH DIFFERENT SEVERITY AND TIME OF THE MANIFESTATION OF PREECLAMPSIA
}

The aim of the study - to conduct a retrospective analysis of the course of pregnancy and delivery to determine the nature of obstetric and perinatal complications in preeclampsia.

Materials and Methods. The analysis was based on the results of the evaluation of the medical documentation (individual medical records of the pregnant woman, birth histories, developmental histories of the newborn) in 224 pregnant women with preeclampsia and 80 pregnant women without preeclampsia. In addition to the results of the clinical and laboratory examination, the analysis included the severity of preeclampsia and the time of clinical manifestations. The results of the study were statistically processed by methods of mathematical analysis with the determination of the mean values $(\mathrm{M} \pm \mathrm{m})$, Student's t-test and significance factor $(p<0.050$ difference was statistically significant.

Results and Discussion. According to the results of the analysis, mild preeclampsia was found in $32.6 \%$ of cases, moderate PE - in $37.5 \%$, severe PE - in $29.9 \%$ of cases. The early onset of PE (up to 34 weeks) was observed in $35.7 \%$ of pregnant women, and later onset (after 34 weeks) in $64.7 \%$. The analysis of the incidence of early and late PE cases at various severity levels showed that, in the case of early PE, severe disease was 2.9 times more frequent, and the moderate disease was 2.7 times more frequent than the mild disease. In the late PE, the mild PE was 1.9 times more frequent than the severe PE and 1.2 times more frequent than the moderate PE. In addition to PE, $31.7 \%$ of women had other complications of pregnancy. The most common complications include asymptomatic bacteriuria (16.9\%), abnormal placental location (14.1\%), placental dysfunction (32.4\%), and fetal growth retardation (21.1\%). Term delivery occurred in $81.6 \%$ of cases, premature births were in $18.3 \%$. Complications include premature rupture of membranes, anomalies of labor, premature detachment of the normally located placenta, postpartum hemorrhage. Among perinatal complications, fetal growth retardation, hemodynamic disorders, fetal distress, newborn asphyxia have been observed. The adverse outcome for a child in severe PE was 3 times higher than for mild PE.

Conclusion. The analysis showed that obstetric and perinatal outcomes in preeclampsia are associated with the time of this pregnancy complication and its severity.

Key words: pregnancy; preeclampsia; obstetric; perinatal outcomes.

АКУШЕРСЬКІ Й ПЕРИНАТАЛЬНІ НАСЛІДКИ У ВАГІТНИХ ІЗ РІЗНИМ СТУПЕНЕМ ТЯЖКОСТІ ТА СТРОКАМИ МАНІФЕСТАЦІї ПРЕЕКЛАМПСІї

Мета дослідження - провести ретроспективний аналіз перебігу вагітності та пологів для визначення характеру акушерських і перинатальних ускладнень при прееклампсії.

Матеріали та методи. Аналіз проведено за результатами оцінки медичної документації (індивідуальних карт спостереження вагітної і породіллі, історій пологів, історій розвитку новонародженого) 224 вагітних із прееклампсією і 80 вагітних без прееклампсії. Крім результатів клініко-лабораторного обстеження, аналіз включав оцінку ступеня тяжкості прееклампсії та терміни її клінічних проявів. Статистичну обробку результатів дослідження проводили методами математичного аналізу 3

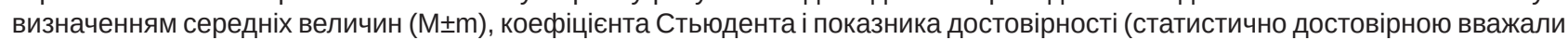
різницю $\mathrm{p}<0,05)$.

Результати дослідження та їх обговорення. За результатами аналізу встановлено, що легкий ступінь прееклампсії зустрічався в 32,6 \% випадків, середній ступінь - в 37,5 \%, тяжкий - у 29,9 \% випадків. Ранній початок ПЕ (до 34 тижнів) відзначено у 35,7 \% вагітних, пізній - (після 34 тижнів) - 64,7 \%. Аналіз частоти випадків ранньої та пізньої ПЕ при різному її ступені тяжкості показав, що при ранній ПЕ тяжкий ступінь зустрічався в 2,9 раза, а середній - в 2,7 раза частіше, ніж легкий ступінь. При пізній ПЕ легкий ступінь ПЕ відзначено в 1,9 раза частіше, ніж тяжкий ступінь, і в 1,2 раза частіше, ніж середній ступінь ПЕ. Крім ПЕ, інші ускладнення вагітності мали 31,7 \% жінок. Найбільш часто відзначено наявність безсимптомної бактеріурії - 16,9 \%, аномального розташування плаценти - 14,1 \%, плацентарної диссрункції - 32,4 \%, затримки росту плода - 21,1 \%. Термінові пологи відбулися в 81,6 \% випадків, передчасні - в 18,3 \%. Серед ускладнень пологів були передчасне вилиття навколоплідних вод, аномалії пологової діяльності, передчасне відшарування нормально розташованої плаценти, післяпологові кровотечі. Серед перинатальних ускладнень відзначені затримка росту плода, гемодинамічні порушення, дистрес плода, ассріксія новонародженого. Несприятливий результат для дитини при тяжкому ступені і ПЕ був в 3 рази вищий, ніж при легкому ступені.

Висновок. Проведений аналіз показав, що акушерські й перинатальні наслідки при прееклампсії пов'язані з термінами розвитку даного ускладнення вагітності та ступенем його тяжкості.

Ключові слова: вагітність; прееклампсія; акушерські наслідки; перинатальні наслідки.

АКУШЕРСКИЕ И ПЕРИНАТАЛЬНЫЕ ИСХОДЫ У БЕРЕМЕННЫХ С РАЗЛИЧНОЙ СТЕПЕНЬЮ ТЯЖЕСТИ И СРОКАМИ МАНИФЕСТАЦИИ ПРЕЭКЛАМПСИИ

Цель исследования - провести ретроспективный анализ течения беременности и родов для определения характера акушерских и перинатальных осложнений при преэклампсии.

Материалы и методы. Анализ проведен по результатам оценки медицинской документации (индивидуальных карт наблюдения беременной и родильницы, историй родов, историй развития новорожденного) 224 беременных с преэклампсией 
и 80 беременных без преэклампсии. Кроме результатов клинико-лабораторного обследования, анализ включал оценку степени тяжести преэклампсии и сроки ее клинических проявлений. Статистическая обработка результатов исследования

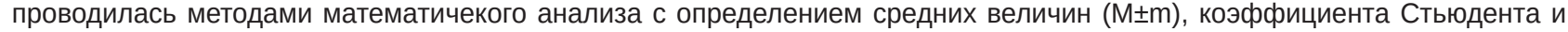
показателя достоверности (статистически достоверной считали разницу $p<0,05)$

Результаты исследования и их обсуждение. По результатам анализа установлено, что легкая степень преэклампсии встречалась в 32,6 \% случаев, средняя степень - в 37,5 \%, тяжелая - у 29,9 \% случаев. Раннее начало ПЭ (до 34 недель) отмечено у 35,7 \% беременных, позднее - (после 34 недель) - 64,7 \%. Анализ частоты случаев ранней и поздней пЭ при различной ее степени тяжести показал, что при ранней ПЭ тяжелая степень встречалась в 2,9 раза, а средняя - в 2,7 раза чаще, чем легкая степень. При поздней пЭ легкая степень ПЭ отмечена в 1,9 раза чаще, чем тяжелая степень, и в 1,2 раза чаще, чем средняя степень ПЭ. Кроме ПЭ, другие осложнения беременности имели 31,7 \% женщин. Наиболее часто отмечено наличие бессимптомной бактериурии - 16,9 \%, аномального расположения плаценты - 14,1 \%, плацентарной дисфункции - 32,4 \%, задержки роста плода - 21,1 \%. Срочные роды произошли в 81,6 \% случаев, преждевременные - в $18,3 \%$. Среди осложнений родов были преждевременное излитие вод, аномалии родовой деятельности, преждевременная отслойка нормально расположенной плаценты, послеродовые кровотечения. Среди перинатальных осложнений отмечены задержка роста плода, гемодинамические нарушения, дистресс плода, асфиксия новорожденного. Неблагоприятный результат для ребенка при тяжелой степени и пЭ был в 3 раза выше, чем при легкой степени.

Вывод. Проведенный анализ показал, что акушерские и перинатальные исходы при преэклампсии связаны со сроками развития данного осложнения беременности и степенью его тяжести.

Ключевые слова: беременность; преэклампсия; акушерские исходы; перинатальные исходы.

INTRODUCTION. Preeclampsia (PE) remains the most serious complication of pregnancy, which is life-threatening for both mother and child. The incidence of PE ranges from 7 $\%$ to $16 \%$, depending on geographical variations [1-3], but investigators do not report a clear downward trend. Severe preeclampsia with increased incidence over the last years is one of the first causes of maternal and perinatal morbidity and mortality [1]. PE increases the risk of placental abruption, massive bleeding, and placental dysfunction. Moreover, severe PE causes the onset of preterm labour or requires premature delivery $[4,5]$. PE is the main cause of the perinatal hypoxic damage, foetal growth retardation, foetal death $[2,4$, 5], and prematurity.

Today it has been proven that the course of preeclampsia and its consequences depend not only on its severity, but on the duration of its clinical manifestations [6].

Preeclampsia can develop up to 34 weeks (early onset) and after 34 weeks (late onset), in the intrapartum or postpartum period. According to the latest scientific data, early and late preeclampsia has different pathogenesis and clinical manifestations [6]. The early preeclampsia is considered to be of placental origin and is associated with primary placental insufficiency and foetal growth retardation, while late PE is associated with mother's extragenital pathology, which is related to impaired fat metabolism, chronic hypertension, renal disease and is commonly associated with foetal distress [5, 6].

Despite a certain amount of studies on various forms of preeclampsia, additional information about their similarities and differences to determine their effective diagnosis and management should be accumulated. Due to the prediction of the course and consequences of various forms and severity of preeclampsia, maternal and perinatal outcomes could be improved.

THE AIM OF THE STUDY - to conduct a retrospective analysis and to determine the pattern of obstetric and perinatal complications at different periods of manifestation and in varying severity of preeclampsia.

MATERIALS AND METHODS. The analysis was based on the results of the evaluation of the medical documentation (individual medical records of the pregnant woman, birth histories, developmental histories of the newborn) in 224 pregnant women with preeclampsia and 80 pregnant women without preeclampsia. Preeclampsia and its severity were diagnosed in accordance with the current orders of the Ministry of Health of Ukraine on the provision of medical care for pregnant women with hypertension [7].

In addition to the results of the clinical and laboratory examination, the analysis included the severity of preeclampsia and the time of clinical manifestations. Preeclampsia was diagnosed based on clinical and laboratory data. One of the main criteria for assessing the severity of preeclampsia was the duration of its course from the initial gestational age, at which the first significant signs appeared.

Additional clinical and laboratory criteria for preeclampsia were used according to the Order of the Ministry of Health of Ukraine to confirm the severity [7].

The pattern of obstetric and perinatal complications that developed during pregnancy, intrapartum, postpartum and neonatal periods in patients with preeclampsia was analysed.

The results of the study were statistically processed by methods of mathematical analysis with the determination of the mean values $(\mathrm{M} \pm \mathrm{m})$, Student's t-test and significance factor $(p<0.050)$ difference was statistically significant.

RESULTS AND DISCUSSION. According to the results of the analysis, mild preeclampsia was found in 73 (32.6\%) cases, moderate PE in 84 (37.5\%), and severe PE in 67 (29.9\%) cases.

The early onset of PE (up to 34 weeks) was observed in 80 (35.7\%) pregnant women, and late onset (after 34 weeks) in 144 (64.7\%). Summary data are presented in Table 1.

The analysis of the incidence of early and late PE cases at various severity levels showed that, in the case of early $\mathrm{PE}$, severe disease was 2.9 times more frequent, and the moderate disease was 2.7 times more frequent than the mild disease. In the late PE, the mild PE was 1.9 times more frequent than the severe PE and 1.2 times more frequent than the moderate PE.

The age analysis of pregnant women showed that preeclampsia was more common in women of older reproductive age (Table 2 ). 
Акушерство та гінекологія

Table 1. Structure of the distribution of pregnant women with preeclampsia according to the form and severity (abs, \%)

\begin{tabular}{|l|c|c||}
\hline \multirow{2}{*}{\multicolumn{1}{|c|}{ PE severity }} & \multicolumn{2}{|c||}{ Pregnant with preeclampsia, $\mathrm{n}-224$} \\
\cline { 2 - 3 } & Early PE, $\mathrm{n}-80$ & Late PE, $\mathrm{n}-144$ \\
\hline Mild, $\mathrm{n}-\mathrm{73}$ & $13-16.3 \%$ & $60-41.7 \%$ \\
\hline Moderate, $\mathrm{n}-84$ & $32-40.0 \%$ & $52-36.1 \%$ \\
\hline Severe, $\mathrm{n}-67$ & $35-43.8 \%$ & $32-22.2 \%$ \\
\hline
\end{tabular}

Table 2. Age parameters in pregnant women with preeclampsia (abs., \%)

\begin{tabular}{|c|c|c|c|c|c|c|c|}
\hline \multirow{3}{*}{ Age, years } & \multirow{3}{*}{$\begin{array}{l}\text { Healthy } \\
\text { pregnant } \\
\text { women, } \\
(\mathrm{n}-80)\end{array}$} & \multicolumn{6}{|c|}{ Pregnant women with preeclampsia, n-224 } \\
\hline & & \multicolumn{2}{|c|}{ Mild, n-73 } & \multicolumn{2}{|c|}{ Moderate, $\mathrm{n}-84$} & \multicolumn{2}{|c|}{ Severe, $n-67$} \\
\hline & & early & late & early & late & early & late \\
\hline \multirow[t]{2}{*}{$20-24$} & $35-43.8$ & \multicolumn{2}{|c|}{ 10-13.7 } & \multicolumn{2}{|c|}{$7-8.3$} & \multicolumn{2}{|c|}{$5-7.5$} \\
\hline & & $2-20.0$ & $8-80.0$ & $2-28.6$ & $5-71.4$ & $3-60.0$ & $2-40.0$ \\
\hline \multirow[t]{2}{*}{$25-29$} & $25-31.3$ & \multicolumn{2}{|c|}{$19-26.0$} & \multicolumn{2}{|c|}{$24-28.6$} & \multicolumn{2}{|c|}{$11-16.4$} \\
\hline & & $4-21.1$ & $15-78.9$ & $10-41.7$ & $14-58.3$ & $6-54.5$ & $5-45.5$ \\
\hline \multirow[t]{2}{*}{ 30-34 } & $16-20.0$ & \multicolumn{2}{|c|}{$23-31.5$} & \multicolumn{2}{|c|}{$31-36.9$} & \multicolumn{2}{|c|}{$31-46.3$} \\
\hline & & $\begin{array}{l}4-17.4 \\
4\end{array}$ & $19-82.6$ & 9-29.0 & $22-71.0$ & $14-45.2$ & $17-54.8$ \\
\hline \multirow[t]{2}{*}{$\geq 35$} & $4-5.0$ & \multicolumn{2}{|c|}{$21-28.8$} & \multicolumn{2}{|c|}{$22-26.2$} & \multicolumn{2}{|c|}{$20-29.8$} \\
\hline & & $3-14.3$ & $18-85.7$ & $11-50.0$ & $11-50.0$ & $12-60.0$ & $8-40.0$ \\
\hline
\end{tabular}

Based on the analysis of this parameter depending on the severity and time of the onset of $\mathrm{PE}$, it can be concluded that in mild $\mathrm{PE}$, the percentage of women with late pre-eclampsia increased with age. In moderate and, in particular, in severe PE, the percentage of women with early preeclampsia increased.

Thus, based on the data obtained, preeclampsia was more common in late pregnancy.

The analysis of the course of pregnancy included all complications of the gestational process.

In addition to PE, 71 (31.7\%) pregnant women with preeclampsia had other complications of pregnancy: complications were observed in $23(32.4 \%)$ pregnant women with early preeclampsia, and in $48(67.6 \%)$ with late PE. At various severity of $\mathrm{PE}$, complications were observed in 18 (25.4\%) patients with mild disease, in 25 (35.2\%) with moderate disease and in 28 (39.4\%) with severe disease. Other gestational complications in pregnant women with $\mathrm{PE}$ were observed by 1.4 times more often in moderate disease and by 1.5 times more often in severe disease compared to mild disease and were by 2 times more often in late PE.

The most common complications include placental dysfunction (32.4\%) and foetal growth retardation (21.1\%). Asymptomatic bacteriuria (16.9\%) and abnormal placental location (14.1\%) were observed less frequently.

Based on the analysis of the labour outcomes, it was found that term delivery occurred in $183(81.6 \%)$, preterm delivery was in $41(18.3 \%)$. It should be noted that the majority $(61.0 \%)$ of preterm birth was among pregnant women with early preeclampsia. Preterm birth was observed with the same frequency both in pregnant women with early and late PE. The highest percentage of term labour was observed in pregnant women with late and mild PE. The structure of labour in pregnant women with pre-eclampsia according to the form and severity is presented in Figure1.

Based on the analysis of the pattern and frequency of labour complications with various severity of preeclampsia, it should be noted that PE complications occurred more frequently in moderate PE (by 1.5 times) and severe PE (by 1.9 times) than in mild PE, and early preeclampsia was associated with labour complications by 1.4 times more frequent, especially in severe cases of PE.

Complications include premature rupture of membranes (28.8\%, $33.3 \%, 44.8 \%$ respectively according to their severity), labour abnormalities (43.8 \%, $42.9 \%, 46.3 \%)$, placental abruption (17.8\%, $21.4 \% .20 .9 \%)$, postpartum haemorrhage $(19.2 \%, 19.0 \%, 22.4 \%)$, foetal distress (30.1\%, 33, $3 \%, 40.3 \%)$. According to the data obtained, the frequency of labour complications was higher in moderate and severe PE, while its early onset was more often associated with labour complications due to the severity of $\mathrm{PE}$ and foetal state.

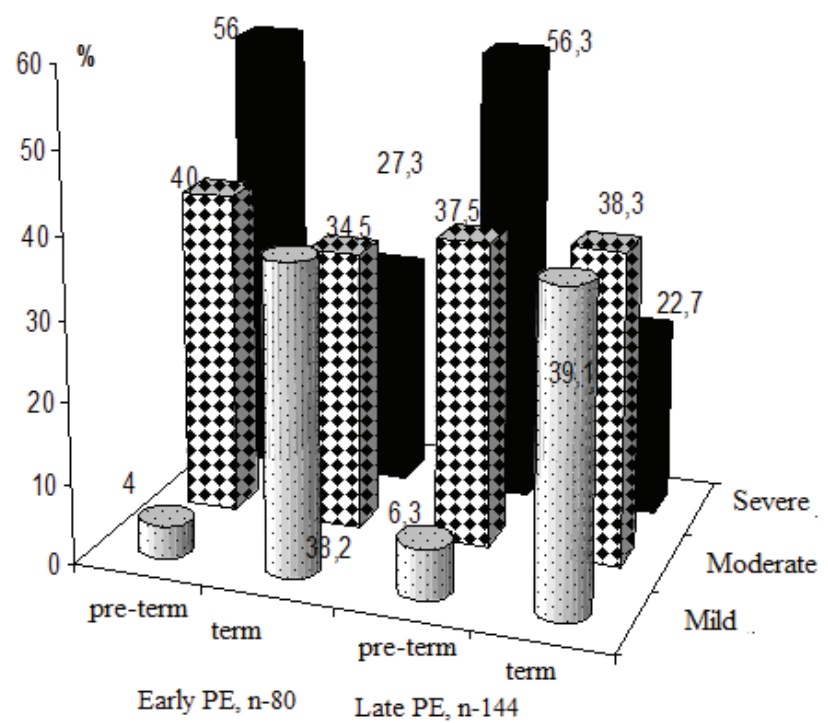

Fig. 1. Structure of labour in pregnant women with preeclampsia according to its form and severity. 
Surgical delivery was performed in 79 (35.3\%) pregnant women with $\mathrm{PE}$ :

in $22.7 \%$ of women with mild PE, in $40.5 \%$ with moderate $\mathrm{PE}$ and in $36.7 \%$ with severe PE. Among pregnant women, $36(45.6 \%)$ had early PE and $43(54.4 \%)$ had late PE.

Thus, it should be noted that the labour outcomes depend not only on the severity of preeclampsia, but on the period of its onset, which certainly affects the obstetric and perinatal outcomes.

A comparative analysis of the labour pattern showed that complicated labour was significantly more often associated with adverse perinatal consequences.

The foetal outcome was relatively favourable in $87.7 \%$ of women with mild PE, in $78.6 \%$ with moderate PE and even in $67.2 \%$ with severe PE.

The frequency of perinatal losses is shown in Figure 2.

Children born from mothers with varying severity of preeclampsia had complications in the neonatal period (9.6 \% in mild PE, $14.3 \%$ in moderate PE, and $19.4 \%$ in severe PE). Consequently, the adverse outcome for a child in severe PE was 3 times higher than for mild PE.

CONCLUSIONS. Thus, based on the analysis of the retrospective study, we can state that preeclampsia is important as a factor of obstetric and perinatal complications, the pattern of which depends on the severity and the onset of clinical manifestations of preeclampsia. Timely prediction of the course of pregnancy and its outcomes will provide the appropriate management of pregnancy and labour for the prevention of adverse effects in mother and foetus

\section{LIST OF LITERATURE}

1. Давыдова Ю. В. Перинатальное управление в преэклампсии с точки зрения управления рисками / Ю. В. Давыдова // Репродуктивная эндокринология. - 2014. - № 4 (18). - C. 72-73.

2. Hutcheon J. A. Epidemiology of preeclampsia and the other hypertensive disorders of pregnancy / J. A. Hutcheon, S. Lisonkova, K. S. Joseph // Best Pract. Res. Clin. Obstet. Gynaecol. - 2011. - Vol. 25, No. 4. - P. 391-403.

3. Gathiram P. Pre-eclampsia: its pathogenesis and pathophysiology / P. Gathiram, J. Moodley // Cardiovascular Journal of Africa. - 2016. - Vol. 27, No. 2. - P. 71-78.

\section{REFERENCES}

1. Davydova, Yu.V. (2014). Perinatalnoye upravleniye v preeklampsii $\mathrm{s}$ tochki zreniya upravleniya riskami [Perinatal management in pre-eclampsia from the standpoint of risk management]. Reproduktivnaya endokrinologiya - Reproductive Endocrinology, 4 (18), 72-73 [in Russian].

2. Hutcheon, J.A. (2011). Epidemiology of preeclampsia and the other hypertensive disorders of pregnancy. Best Pract. Res. Clin. Obstet. Gynaecol., 25, 4, 391-403.

3. Gathiram, P., \& Moodley, J. (2016). Pre-eclampsia: its pathogenesis and pathophysiology. Cardiovascular Journal of Africa, 27, 2, 71-78.

4. Nagornaya, V.F. (2013). Gestozy [Gestozis]. "Zdorovia Ukrainy" (Hinekolohiia. Akusherstvo. Reproduktolohiia) - "Health of Ukraine" (Gynecology, Obstetrics, Reproduction), 1, 35-37 [in Ukrainian].

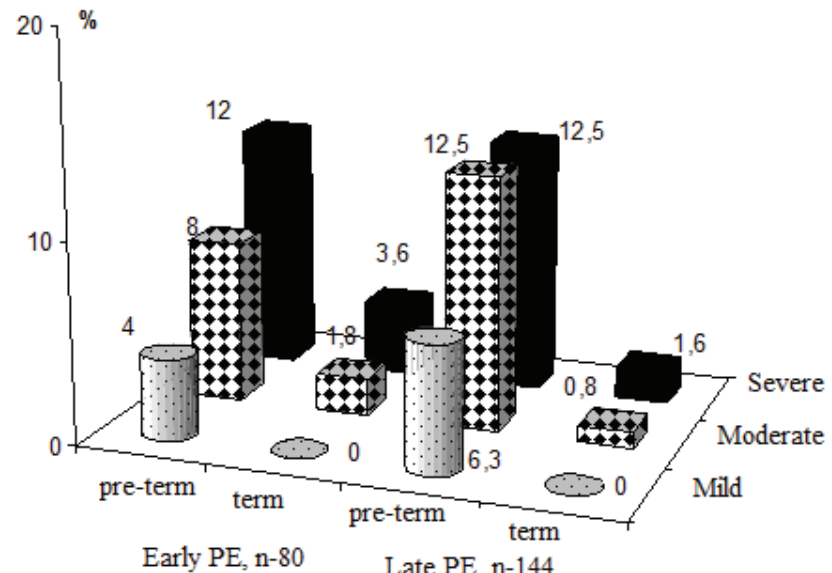

Fig. 2. Frequency of perinatal loss in pregnant women with preeclampsia according to form and severity (abs, \%).

PERSPECTIVES OF FURTHER RESEARCH. The determination of the pattern and frequency of obstetric and perinatal complications in women with various forms and degrees of severity of pre-eclampsia will be aimed at identification of their pathogenetic mechanisms to develop the appropriate options for management of pregnancy and labour in patients with pre-eclampsia to improve outcomes.
4. Нагорная В. Ф. Гестозы / В. Ф. Нагорная // "Здоров'я України” (Гінекологія. Акушерство. Репродуктологія). - 2013. - № 1. - С. 35-37.

5. Современные подходы к диагностике преэклампсии / П. Н. Веропотвелян, Н. П. Веропотвелян, Е. П. Смородская // Здоровье женщины. - 2013. - № 8. - С. 79-84. - Режим доступа : http://nbuv.gov.ua/UJRN/Zdzh_2013_8_21.

6. Лоскутова Т. О. Управление беременными женщинами с риском преэклампсии / Т. О. Лоскутова // Медицинские перспективы. - 2015. - Т. XX, № 1. - Р. 62-69.

7. Наказ № 676 від 31.12.2004 р. “Про затвердження клінічних протоколів з акушерської та гінекологічної допомоги" // Жіночий лікар. - Київ, 2004 [Електронний ресурс]. - Режим доступу : https://z-I.com.ua/ru/new319/.

5. Veropotvelyan, P.N., Veropotvelyan, N.P., \& Smorodskaya, E.P. (2011). Sovremennyye podkhody k diagnostike preeklampsii [Modern approaches to the diagnosis of preeclampsia]. Zdorovye zhenshchiny - Women's Health, 6 (46), 43-52 [in Russian].

6. Loskutova, T.O. (2015). Upravleniye beremennymi zhenshchinami s riskom preeklampsii [Management of pregnant women at risk of preeclampsia]. Meditsinskiye perspektivy Medical Perspectives, XX, 1, 62-69 [in Russian].

7. (2004). Nakaz № 676 vid 31.12.2004 "Pro zatverdzhennia klinichnykh protokoliv z akusherskoi ta hinekolohichnoi dopomohy" [Order No. 676 dated December 31, 2004 "On Approval of Clinical Protocols on Obstetric and Gynecological Aid"]. Zhinochyi likar - Woman's Doctor. Retrieved from: https://z-l.com. ua/ru/new319/ [in Ukrainian]. 